\title{
The risk of arrhythmia by calculating with new electrocardiographic parameters in pregnant women with heart failure
}

\section{Kalp yetersizliği olan hamile kadınlarda yeni elektrokardiyografik parametreler ile aritmi riskinin hesaplanması}

\author{
Hakan GOCER ${ }^{1}$, Ozlem Kayacik GUNDAY², Mustafa UNAL ${ }^{3}$
}

${ }^{1}$ Medical Park Hospital, Cardiology Department, Izmir/TURKEY

${ }^{2}$ KTO Karatay University, Medicana Medical Faculty Hospital, Department of Obstetrics and Gynecology, Konya/TURKEY

${ }^{3}$ Bicard Clinic, Department of Cardiovascular Surgery, Bishkek/KYRGYZSTAN

\begin{abstract}
Aim: To evaluate cardiac arrhythmias with surface 12 lead electrocardiography (ECG) parameters during pregnancy in women with mild heart failure.

Material and Methods: This cross-sectional study was approved by the local ethics committee of bicard clinic and our hospital 53 consecutive patients were accepted. All patients were admitted to hospital for cesarean section. Patients were grouped to heart failure (group 1) and control (group 2) (healthy group). A 12 lead ECG and N-terminal pro B-type natriuretic peptide (NT-pro BNP) plasma levels was recorded for every woman at 48 hour before cesarean section. They were evaluated P wave, qt, qtc and Twave peak to end, preoperative NT-pro BNP and compared statistically.

Results: There were statistically significant differences in the Tp-e interval and Tp-e/QTc ratio between the two groups, the maximum QTc, minimum QTc, and QTc dispersion values, P wave dispersion were significantly higher in group-1 compared to the group-2. In addition, preoperative NT-pro BNP plasma levels was greater in the group 1 pregnant women. And there was a positive correlation between ECG parameters and NT-pro BNP plasma levels in group 1.

Conclusion: In conclusion, repolarization parameters were increased in patients with heart failure with elevated NT-pro BNP. Pregnancy and heart failure has known risk for pregnant women. But there is no clear cut atrial and ventricular arrhythmias risk scoring parameters for these kind patients. We found that ECG parameters which had significantly different in pregnant women with heart failure than control group and these changes correlated with NT-pro BNP levels. This is pathological; arrhythmia risk scorings should be established to reduce mortality and morbidity in heart failure patients with elevated BNP levels.
\end{abstract}

Keywords: Cardiac arrhythmias; repolarization parameters; pregnancy; heart failure; electrocardiography; NT-pro BNP

Corresponding Author: Hakan Gocer, Medical Park Hospital, Cardiology Department, Izmir/TURKEY

E-mail: hgocer@gmail.com

Recevied: 27.09.2018 accepted: 07.11.2018

Doi: $10.18663 /$ tjcl.464494 


\section{Öz}

Amaç: Hafif kalp yetmezliği olan kadınlarda gebelik sırasında 12 elektrokardiyografi (EKG) parametresi ile kardiyak aritmi değerlendirmek.

Gereç ve Yöntemler: Bu kesitsel çalışma, bicard kliniği yerel etik kurul tarafından onaylandı ve hastanemizdeki ardışık 53 hasta kabul edildi. Tüm hastalar sezaryen için hastaneye başvurdu. Hastalar kalp yetmezliği (grup 1) ve kontrol (grup 2) (sağlıklı grup) olarak gruplandırıldı. 12 kanallı EKG ve N-terminal pro B tipi natriüretik peptid (NT-pro BNP) plazma seviyeleri her kadın için sezaryenden önce 48 saatte kaydedildi. P dalgası, qt, qtc ve Twave zirve sonu, preoperatif NT-pro BNP olarak değerlendirildi ve istatistiksel olarak karşılaştıııldı.

Bulgular: Iki grup arasında Tp-e intervali ve Tp-e / QTc oranlarında istatistiksel olarak anlamlı farklılıklar, maksimum QTc, minimum QTc ve QTc dispersiyon değerleri, P dalgası dispersiyonu grup-1'de grup-2 ye göre anlamlı olarak yüksek bulundu.. Ek olarak, grup 1 gebelerde preoperatif NT-pro BNP plazma seviyeleri daha fazlaydı. Ve grup 1'de EKG parametreleri ve NTpro BNP plazma seviyeleri arasında pozitif bir korelasyon vardı.

Sonuç: Sonuç olarak, artmış NT-pro BNP ile kalp yetmezliği olan hastalarda repolarizasyon parametreleri artmıştır. Hamilelik ve kalp yetmezliği, hamile kadınlar için bilinen risktir. Ancak bu tür hastalar için açık atriyal ve ventriküler aritmiler risk skorlama parametreleri yoktur. Kalp yetmezliği olan gebelerde kontrol grubuna göre anlamlı derecede farklı olan EKG parametrelerinin, NT-pro BNP düzeyleri ile korele olduğunu bulduk. Bu patolojik; artmış BNP düzeyi olan kalp yetmezliği hastalarında mortalite ve morbiditeyi azaltmak için aritmi riski skorlamaları oluşturulmalıdır.

Anahtar kelimeler: Kardiyak aritmiler; repolarizasyon parametreleri; gebelik; kalp yetmezliği; elektrokardiyografi; NT-pro BNP

\section{Introduction}

During gestations there are a number of adaptive hemodynamic changes, including increases in plasma volume, heart rate and cardiac output, slightly impaired endothelial dysfunction. Also, in heart failure patients, B-type natriuretic peptide (BNP) increases in response to these types of volume loading conditions and predicts the risk of adverse outcomes in a variety of cardiac conditions [1-6]

Although clinical, biochemical and echocardiographic predictors of adverse cardiac events during pregnancy in heart failure patients have been identified $[7,8]$ risk stratification is incomplete, and current risk stratification does not include evaluation of the adequacy of maternal cardiac adaptation during pregnancy. Furthermore, because the signs and symptoms of pregnancy can mimic those of cardiac decompensation, clinical recognition of heart disease is more difficult during pregnancy and, therefore, there might be a role for additional markers such as Tp-e interval and Tp-e/QTc , the P dispersion.

In a study investigating during pregnancy up until one year postpartum, $22.2 \%$ of maternal deaths were found to be from cardiovascular disease and women with cardiovascular mortality were likely older and die during postpartum. The most frequent etiology was cardiomyopathy, while the arrhythmic deaths were the third most common cause [6]

Although heart failure is well-known to account for an increase in mortality and morbidity during pregnancy, in obstetric problems and for a higher risk of miscarriage, stillbirth, and infant death, no study has evaluated the risk of arrhythmia, which is a major cause of cardiovascular disease in maternal death. Our study aimed to determine the risk of arrhythmia by calculating the electrocardiographic P-wave duration, QT interval, T peak-to-end interval, and the Tp-e/QT ratio in pregnant women with heart failure and elevated BT-pro BNP.

\section{Material and Methods}

This cross-sectional study was approved by the local ethics committee of bicard clinic. All consecutive heart failure patients and patients with normal heart functions (as a control group) in the last trimester according to last menstrual period and ultrasonographic measurements with asymptomatic nulliparous pregnant women who were admitted to the Department of Obstetrics and Gynecology of bicard clinic were considered eligible for the study. In total, 53 pregnant women, of whom 28 were of heart failure with elevated BNP levels(diagnosed as a mild heart failure with echocardiography 
and clinic findings beforehand) (group 1) and 25 were normal heart functions and normal $\mathrm{N}$-terminal pro B-type natriuretic peptide (NT-pro BNP) levels (group 2), were included.

Those with multiple pregnancies, hypertension, diabetes mellitus, gestational diabetes, pre-eclampsia, eclampsia, previous history of pregnancy-induced hypertension, family history, any immunologic-rheumatologic disease, abnormal renal, hepatic, or thyroid function tests, atrial fibrillation, complete or incomplete bundle branch block, ST-T abnormalities, the use of any drugs that could affect Tp-e or QT interval, $U$ waves or negative $T$ waves on electrocardiography (ECG), and electrolyte imbalances were excluded from the study.

A 12-lead ECG (AT-102, Schiller AG, Baar, Switzerland) was recorded for each woman only once at a point in 48 hour before labor at rest while in the supine position. Recordings were acquired at a paper speed of $50 \mathrm{~mm} / \mathrm{s}$, with $1 \mathrm{mV} / \mathrm{cm}$ standardization. We improved our accuracy using calipers and magnifying lenses. The onset of the $P$ wave was defined as the first atrial deflection from the isoelectric line, and the offset was the return of the atrial signal to the baseline. The maximum and minimum $P$ wave duration were measured and their differences were defined as the P dispersion. The QT interval was measured from the beginning of the QRS complex to the end of the T wave and corrected for the heart rate using the Bazett formula: $\mathrm{CQT}=\mathrm{QT} \sqrt{ }(\mathrm{R}-\mathrm{R}$ interval)

The Tp-e interval was defined as the interval between the peak and end of the $T$ wave, measurements of the Tp-e interval were performed from precordial leads, and the Tp-e/QTc ratio was calculated from these measurements.

\section{Statistical Analysis}

Statistical analysis was performed using SPSS 21 (SPSS Inc., Chicago, Illinois). In the interim statistical analysis of the study, the sample size was calculated according to the QTc interval and a sample size of 132 (66 per group) patients would be required with $80 \%$ power and the conventional 2-sided type 1 error of $5 \%$. Data were tested for normality of distribution using the Kolmogorov-Smirnov test. Continuous variables were presented as means followed by the standard deviation and categorical variables as frequencies and percentages. Continuous variables between the two groups were compared using Student's t test for normally distributed data and the Mann-Whitney $U$ test for data that was not normally distributed. Categorical parameters were evaluated by chisquared $(x 2)$ test. Pearson rank tests were used to indicate the correlation of maternal age with QTc duration, Tp-e interval, and Tp-e/QTc ratio. Multivariate linear regression analysis was performed to determine the predictors of QTC dispersion. A two-tailed $P \leq 0.05$ was considered significant

\section{Results}

The obstetric and demographic characteristics of the groups were as presented in Table-I. And study population Laboratory tests results were summarized in Table-Il. There were no statistically significant discrepancies except NT-pro BNP and echocardiographic left ventricular ejection fraction (LVEF). There were statistically significant differences in the Tp-e interval and T-e/QTc ratio and $P$ wave dispersion between the groups, the maximum QTc, minimum QTc, and QTc dispersion values were significantly higher in group-1 compared to the group 2 (Table III). In addition, the pro-NT BNP plasma levels were greater in group 1. Also LVEF were low in group 1 as expected. In bivariate correlation analysis, the dispersion of QTc and P, Tp-e interval, Tp-e/QTc ratio, the maximum QTc, minimum QTc, was positively correlated with NT-Pro BNP levels (Table IV).

\begin{tabular}{|c|c|c|c|}
\hline & $\begin{array}{c}\text { Group-1 (HF- } \\
\text { patients) }\end{array}$ & $\begin{array}{l}\text { Group-2 } \\
\text { (Control) }\end{array}$ & P-value \\
\hline Maternal age, years & $39.5 \pm 2.8$ & $38 . .5 \pm 3.2$ & 0.56 \\
\hline Gestational week & $37.7 \pm 3.5$ & $37.4 \pm 3.4$ & 0.67 \\
\hline $\mathrm{BMI}, \mathrm{kg} / \mathrm{m}^{2}$ & $29.4 \pm 4.9$ & $29.9 \pm 4.3$ & 0.65 \\
\hline Heart rate, bpm & $90.7 \pm 14.8$ & $89.9 \pm 15.5$ & 0.68 \\
\hline Systolic BP, mmHg & $117.4 \pm 9.6$ & $112.4 \pm 10.2$ & 0.56 \\
\hline Diastolic BP, mmHg & $70.1 \pm 8.2$ & $69.8 \pm 7.3$ & 0.48 \\
\hline
\end{tabular}

\begin{tabular}{|c|c|c|c|}
\hline & $\begin{array}{c}\text { Group-1 ( } \geq 35 \\
\text { years) }\end{array}$ & $\begin{array}{c}\text { Group-2 }(<35 \\
\text { years) }\end{array}$ & P-value \\
\hline Hemoglobin (g/dl) & $11.8 \pm 1.3$ & $11.8 \pm 1.2$ & 0.84 \\
\hline Platelet $(\times 103)-/ \mu \mathrm{L}$ & $242.6 \pm 59.4$ & $229.1 \pm 65.0$ & 0.08 \\
\hline WBC & $11508 \pm 2422$ & $12036 \pm 2135$ & 0.10 \\
\hline BUN (mg/dl) & $16.3 \pm 3.9$ & $16.6 \pm 4.7$ & 0.53 \\
\hline Creatinine (mg/dl) & $0.48 \pm 0.08$ & $0.46 \pm 0.07$ & 0.06 \\
\hline Sodium (mEq/L) & $137.4 \pm 1.9$ & $137.8 \pm 1.8$ & 0.42 \\
\hline $\begin{array}{l}\text { Potassium } \\
\text { (mEq/L) }\end{array}$ & $4.1 \pm 0.3$ & $4.1 \pm 0.2$ & 0.93 \\
\hline \multicolumn{4}{|c|}{ WBC: white blood cell, BUN: Blood Urea Nitrogen. } \\
\hline
\end{tabular}




\begin{tabular}{|c|c|c|c|}
\hline & Group-1 (HF) & $\begin{array}{l}\text { Group-2 (Con- } \\
\text { trol) }\end{array}$ & P-value \\
\hline $\begin{array}{l}\text { Maximum QTc } \\
\text { interval (ms) }\end{array}$ & $403.7 \pm 27.8$ & $393.3 \pm 14.6$ & $<0.001$ \\
\hline $\begin{array}{l}\text { Minimum QTc } \\
\text { interval (ms) }\end{array}$ & $391.8 \pm 23.7$ & $343.8 \pm 13.2$ & $<0.001$ \\
\hline $\begin{array}{l}\text { QTc dispersion } \\
\text { (ms) }\end{array}$ & $26.8 \pm 8.7$ & $19.5 \pm 7.2$ & $<0.001$ \\
\hline Tp-e interval (ms) & $96.3 \pm 13.0$ & $74.2 \pm 13.0$ & $<0.001$ \\
\hline Tp-e/QTc ratio & $0.28 \pm 0.03$ & $0.11 \pm 0.13$ & $<0.001$ \\
\hline P dispersion (ms) & $19.5 \pm 7.5$ & $11.8 \pm 7.2$ & $<0.001$ \\
\hline NT-pro BNP (ng/l) & $697 \pm 6.9$ & $180 \pm 6.1$ & $<0.001$ \\
\hline LVEF (\%) & $40 \pm 2.8$ & $57 \pm 2.9$ & $<0.001$ \\
\hline
\end{tabular}

\begin{tabular}{|c|c|}
\hline $\begin{array}{l}\text { Table-IV Corre } \\
\text { diographic find } \\
\text { pregnants. }\end{array}$ & $\begin{array}{l}\text { etween electrocar- } \\
\text { characteristics in }\end{array}$ \\
\hline & NT-pro BNP levels \\
\hline Maximum QTC & $\begin{array}{c}r: 0,244 \\
p:<0,001\end{array}$ \\
\hline Minimum QTC & $\begin{array}{c}r: 0,199 \\
p:<0,001\end{array}$ \\
\hline QTc dispersion & $\begin{array}{l}r: 0,219 \\
p:<0,001\end{array}$ \\
\hline Mean QTC & $\begin{array}{l}r: 0,225 \\
p:<0,001\end{array}$ \\
\hline Tp-e interval & $\begin{array}{l}r: 0,182 \\
p:<0,001\end{array}$ \\
\hline Tp-e/QTc ratio & $\begin{array}{l}r: 0,173 \\
p:<0.001\end{array}$ \\
\hline P dispersion & $\begin{array}{c}\mathrm{r}: 0,232 \\
\mathrm{p}:<0,001\end{array}$ \\
\hline NT-pro BNP levels: N & natriuretic peptide levels. \\
\hline
\end{tabular}

\section{Discussion}

The main findings of our study are that atrial and ventricular repolarization parameters were significantly higher in pregnant women with heart failure and elevated NT-pro BNP levels. In addition, we determined the parameters of atrial and ventricular repolarization were increased with increasing NTpro BNP levels.

In a study evaluating the risk of cardiac arrhythmia in a preeclampsia (PE) group, the maximum QT, QTC dispersion, Tp-e interval, and Tp-e/QTc ratio values were found to be significantly higher in the PE group than in the healthy pregnant group [9]. Another study examining the changes in atrial and ventricular repolarization markers during pregnancy found that $\mathrm{P}$ dispersion, maximum QTC interval, Tp-e interval and Tp-e/QT ratio were increased in late pregnancy, but still remained within the normal range [10]. Recently, Braschi et al. demonstrated the increase in ventricular repolarization markers with increased age [11]. In our study, maximum QTc, minimum QTC, and QTc dispersion values were found to have increased in advanced age pregnancies. In addition, only the maternal age was determined as a predictor of the QT dispersion.

The electrocardiogram is a common, simple medical tool used for predicting arrhythmogenic risk in clinical practice. The QT interval and its correction by heart rate (QTC), QT interval dispersion, and recently published markers such as the Tp-e interval and Tp-e/QTc ratio have been proposed as markers for predicting the development of malign cardiac arrhythmia and recommended as alternatives for the risk stratification of sudden cardiac death in women with several medical conditions [12-14]. But there is a lack of evidence about pregnant women with heart failure. Furthermore, the NT-pro BNP levels and its relationship with ECG parameters in pregnant women with heart failure have not been studied. We were evaluated the study group according to both ECG parameters and NT-pro BNP levels. And we found positive relation with ECG parameters and NT-pro BNP levels. It supports our hypothesis and can reveal that these kinds of ECG parameters must be took into consideration during estimation of all pregnant women with any kind of structural heart disease.

The clinician is often consulted to examine a pregnant woman for the presence of cardiovascular disease. Electrocardiography can detect the physiological adaptations in the maternal cardiovascular system, but the results should be interpreted with caution as they mislead to the diagnosis of heart disease [15]. We try to demonstrate the risk of arrhythmia in pregnant women with heart failure with new repolarization parameters in our study. We found that (QTC), QT interval dispersion, P wave dispersion, Tp-e interval and T-e/QTc ratio can be used all together in pregnant women with heart failure. Also findings of our study correlated with some preeclampsia studies which demonstrated preeclampsia triggers an alteration of atrial depolarization and ventricular repolarization, which are evidenced by the prolongation of ECG parameters such as $\mathrm{P}$ wave dispersion and QTC dispersion. ECG is a noninvasive, easy to use, and easily available diagnostic tool, which can 
be used in the assessment of atrial and ventricular electrical activity in pregnant women with preeclampsia [16]. But there is no studies that shows ventricular arrhythmic risk with (QTc), QT interval dispersion, $\mathrm{P}$ wave dispersion with all together other repolarization parameters such as Tp-e interval and T-e/QTc ratio in pregnant women with heart failure. Also there were some isolated results about $P$ wave dispersion which demonstrated that shortening of the minimum P-wave duration leads to increased P-wave dispersion during pregnancy [17]. Moreover in one study showed us even if living at moderately high altitude in term pregnant women could change QT interval [18]. We evaluated all these parameters and biochemical parameters in specific group.

Our study showed that, ECG repolarization parameters as a arrhythmia risk markers were found high in pregnant women with heart failure and positively correlated with NT-pro BNP levels.

\section{Conclusion}

In conclusion, although study population was small, the repolarization parameters were increased in pregnant women with heart failure and elevated NT-pro BNP. To obtain these repolarization parameters are easy and usage of these parameters as a cardiac arrhythmic risk factor are logical. But the validity of the usage of these ECG parameters in pregnant women with cardiac disorders (Herat failure etc.) should be explained in further studies .arrhythmia risk scorings should be established to reduce mortality and morbidity in cardiac disorders especially heart failure with last trimester pregnant women.

\section{Declaration of conflict of interest}

The authors received no financial support for the research and/or authorship of this article. There is no conflict of interest.

\section{References}

1. Astolfi P, Zonta L. Delayed maternity and risk at delivery. Paediatr Perinat Epidemiol 2002; 16: 67-72.

2. Tough SC, Newburn-Cook C, Johnston DW, Svenson LW, Rose $S$, Belik J. Delayed childbearing and its impact on population rate changes in lower birth weight, multiple birth, and preterm delivery. Pediatrics 2002; 109: 399-403.

3. Bateman BT, Simpson LL. Higher rate of stillbirth at the extremes of reproductive age:a large nationwide sample of deliveries in the United States. Am J Obstet Gynecol 2006; 194: 840-45.

4. Di Mario S, Say L, Lincetto O. Risk factors for stillbirth in developing countries:a systematic review of the literature. Sex Transm Dis 2007; 34: 11-21.
5. Jacobsson B, Ladfors L, Milsom I. Advanced maternal age and adverse perinatal outcome. Obstet Gynecol 2004; 104: 727-33.

6. Briller J, Koch AR, Geller SE. Maternal Cardiovascular Mortality in Illinois, 2002-2011. Obstet Gynecol 2017; 129: 819-26.

7. Shotan A, Ostrzega E, Mehra A, Johnson JV, Elkayam U. Incidence of arrhythmias in normal pregnancy and relation to palpitations, dizziness, and syncope. Am J Cardiol. 1997; 79: 1061-64.

8. Rosano GM, Leonardo F, Sarrel PM, Beale CM, De Luca F, Collins P. Cyclical variation in paroxysmal supraventricular tachycardia in women. Lancet 1996; 347: 786-68.

9. Kirbas $A$, Kirbas $O$, Daglar $\mathrm{K}$ et al. Novel indexes of arrhythmogenesis in preeclampsia:QT dispersion, Tp-e interval, and Tp-e/QT ratio. Pregnancy Hypertens 2016; 6: 38-41.

10. Tanindi A, Akgun N, Pabuccu EG et al. Electrocardiographic P-Wave Duration, QT Interval, T Peak to End Interval and Tp-e/QT Ratio in Pregnancy with Respect to Trimesters. Ann Noninvasive Electrocardiol 2016; 21: 169-74.

11. Braschi A, Abrignani MG, Francavilla VC, Abrignani V, Francavilla G. Age- and sex-based reference ranges for non-invasive ventricular repolarisation parameters. Int J Clin Pract 2017; 71

12. Elming $H$, Holm $E$, Jun $L$ et al. The prognostic value of the QT interval and QT interval dispersion in all-cause and cardiac mortality and morbidity in a population of Danish citizens. Eur Heart J 1998; 19: 1391-400.

13. Malik M, Batchvarov VN. Measurement, interpretation and clinical potential of QT dispersion. J Am Coll Cardiol 2000; 36: 1749-66.

14. Castro Hevia J, Antzelevitch C, Tornes Barzaga F et al. TpeakTend and Tpeak-Tend dispersion as risk factors for ventricular tachycardia/ventricular fibrillation in patients with the Brugada syndrome. J Am Coll Cardiol 2006; 47: 1828-34.

15. V Madras, $\mathrm{N}$ Challa.Electrocardiographic variations during three trimesters of normal pregnancy. Int J Res Med Sci 2015; 3: 2218-22.

16. Hüseyin Altuğ Çakmak, Burcu Dinçgez Çakmak, Gülten Özgen, Mehmet Gül , Ayşe Ender Yumru. P-Wave and QT Dispersion in Pregnant Women with Preeclampsia. Jarem 2016; 6: 170-76.

17. Ozmen N, Cebeci BS, Yiginer O, Muhcu M, Kardesoglu E, Dincturk M. P-wave dispersion is increased in pregnancy due to shortening of minimum duration of $\mathrm{P}$ : does this have clinical significance. J Int Med Res 2006; 34: 468-74.

18. Batmaz G, Aksoy AN, Aydın S, Ay NK, Dane B. QT interval changes in term pregnant women living at moderately high altitude. Niger J Clin Pract 2016; 19: 611-15. 